American Journal of

Supply Chain Management

(AJSCM)

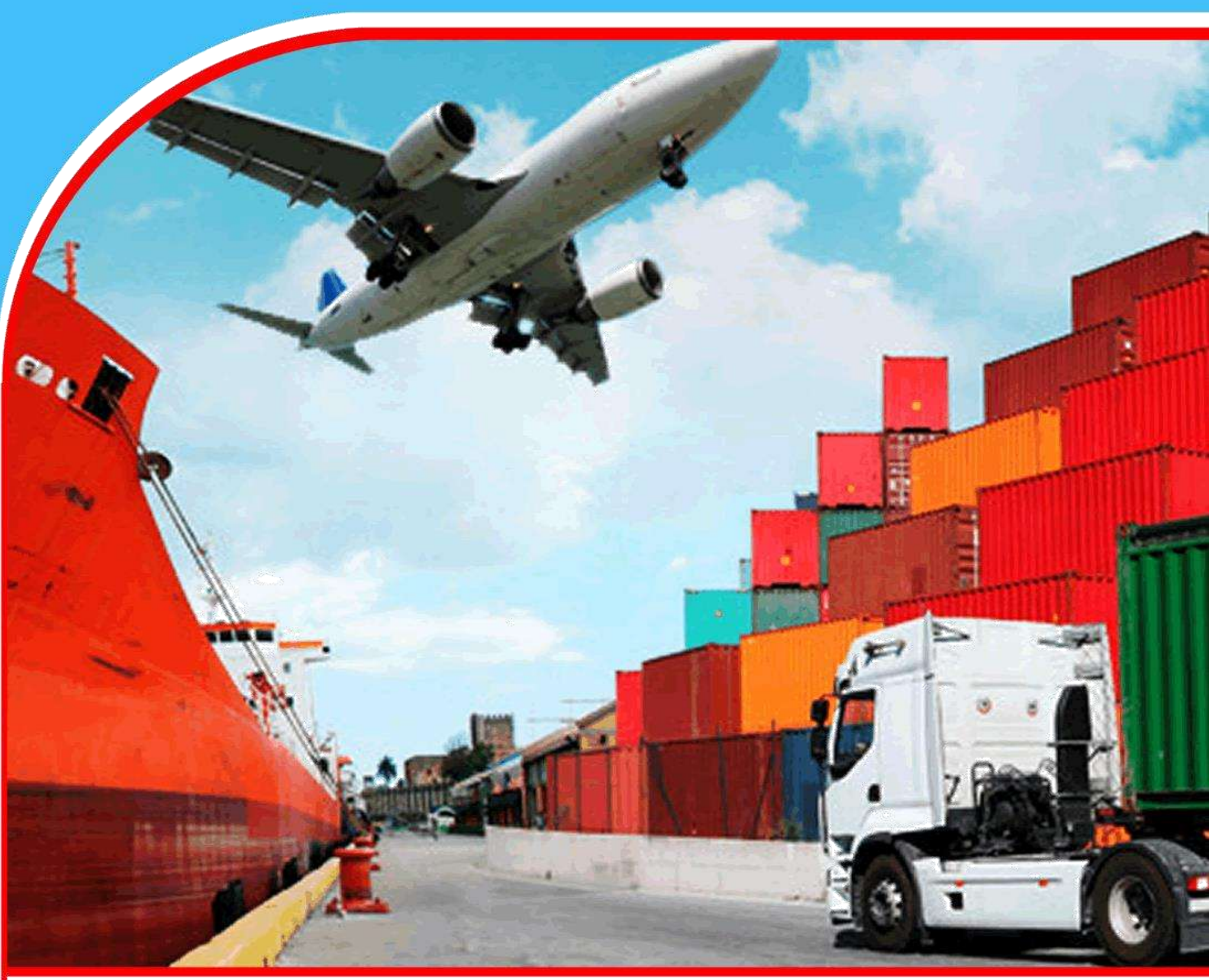

EFFECTS OF GREEN PROCUREMENT

ADOPTION ON THE SUPPLY CHAIN

PERFORMANCE AT BATA SHOE COMPANY LIMITED, KENYA

Racheal Wanjiru Njoroge and Dr. Mike A. Iravo

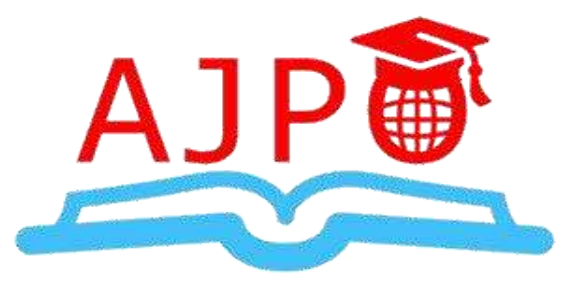




\title{
EFFECTS OF GREEN PROCUREMENT ADOPTION ON THE SUPPLY CHAIN PERFORMANCE AT BATA SHOE COMPANY LIMITED, KENYA
}

\author{
1* Racheal Wanjiru Njoroge \\ 1* Post Graduate Diploma student, Jomo Kenyatta University of Agriculture and Technology \\ *Corresponding Author's Email: rachealwn1@gmail.com \\ ${ }^{2}$ Dr. Mike A. Iravo \\ Lecturer, Jomo Kenyatta University of Agriculture and Technology
}

\begin{abstract}
Purpose: This purpose of the study was to determine the effects of adopting green procurement on the supply chain performance at Bata Shoe Company in Kenya

Methodology: This study adopted descriptive research design. The target population was 120 employees working in different levels of management who are directly involved in managing distribution activities in the organization. The sampling frame was the Human Resource register at BATA Kenya. The population sample was 120 respondents. Structured questionnaires containing both open ended and closed ended questions were used to collect primary data. The questionnaires were filled and returned for analysis. The data collected was analyzed using descriptive statistics like percentages, standard deviations, frequency tables among others. The Statistical Package for Social Sciences (SPSS) Version 17 software was used.

Results: Results indicated that quality management, organizational policy, information technology integration and demand management have a positive and significant relationship on supply chain performance at BATA

Unique contribution to theory, practice and policy: This study recommends that BATA should review its organizational policy on JIT implementation to improve its supply chain performance especially in regards to better human resource management practices. BATA should also enhance its Information Technology Integration to promote information sharing and support its ERP systems.
\end{abstract}

Key words: green procurement, supply chain performance, quality management, information technology integration and demand management 


\subsection{INTRODUCTION}

\subsection{Background of the Study}

There is an increased amount of pollution waste in our marine environment, streets, storm drains and landfills. These pollutants, impractical to recycle due to their lightweight, are the most common form of marine debris and cost local governments millions in storm drain clean up costs. These costs are especially high for communities with impaired waterways.

With the coming of the Industrial Revolution, humans were able to advance further into the $21 \mathrm{st}$ century. Technology developed rapidly, science became advanced and the manufacturing age came into view. With all of these came one more effect, industrial pollution. Earlier, industries were small factories that produced smoke as the main pollutant. However, since the number of factories were limited and worked only a certain number of hours a day, the levels of pollution did not grow significantly. But when these factories became full scale industries and manufacturing units, and demand for the goods went up, the issue of industrial pollution started to take on more importance.

Most of the pollution on the planet can be traced back to industries of some kind. In fact, the issue of industrial pollution has taken on grave importance for agencies trying to fight against environmental degradation. Countries facing sudden and rapid growth of such industries are finding it to be a serious problem, which has to be brought under control immediately.

Consumers, investors, shareholders and regulatory agencies are increasingly demanding that organizations behave in an environmentally responsible manner. Practicing green procurement demonstrates an organization's commitment to considering and minimizing the environmental consequences of its activities. Green products are generally produced in a manner that consumes less natural resources or uses them more sustainably, as with sustainable forestry. They may involve less energy in their manufacture and may consume less energy when being used, and they generally contain fewer hazardous or toxic materials.

Green products are also generally designed with the intention of reducing the amount of waste created. For example, they may contain recycled material or use less packaging, and the supplier may operate a take-back program. Green procurement can also offer cost savings. In particular, buying green usually involves products that are easily recycled, last longer or produce less waste. Money is therefore saved on waste disposal. In addition, green products generally require fewer resources to manufacture and operate, so savings can be made on energy, water, fuel and other natural resources.

Moreover, green products generally involve fewer toxic or hazardous materials, reducing associated expenses such as permit fees, toxic materials handling charges and staff training. Manufacturers often require a green procurement program as part of their environmental management systems, as certified under the EMAS and ISO 14001 regimes. In addition, new regulations increasingly require the adoption of green procurement practices. The Sustainable Development Act in Manitoba, for example, requires all publicly funded organizations to integrate procurement guidelines into their daily operating practices.

Meeting these and other environmental regulations is easier for organizations that already practice green procurement. Green procurement also has benefits for health and safety, both of workplaces and of the wider community. Organizations that practice green procurement will also 
be recognized as good corporate citizens, and influence those around them. As markets gradually change, the availability of green products will increase and prices will fall.

Bata Kenya was the result of visits by a group of Bata employees to Kenya 80 years ago. They came to buy hides for the factory in Czechoslovakia. In 1935, a trading company was established in Mombasa to import shoes from Zlin to sell in the local market. In 1938, Bata rented a small soap factory building in Mombasa to begin the production of rubber and canvas footwear. Two years later, the factory moved to its current location in the pleasant green highlands of Limuru, on the edge of Rift Valley.

Today Bata Kenya has grown to be the market leader in manufacturing, selling, and distribution of footwear in Kenya and East Africa. The company adapts to customers' requirements, focuses on continuous improvements, and maintains harmony between its business and social responsibilities. The company's production facility is very integrated. Annual production is around 31 million pairs, including injected plastic, cemented shoes for school and safari, and thongs. The installation of new machines and expansion of the sales network has increased market participation significantly, and annual production increased by 2.5 times in the last decade.

Bata Kenya produces for more than just its domestic market; it also produces shoes for neighboring countries including Malawi and Uganda. With the advancement of the Rhino project, regional demands are likely to increase, and the Limuru factory will become the manufacturing hub for the region.

\subsection{Statement of the problem}

The researchers found that more than two-thirds of a running shoe's carbon impact can come from the manufacturing processes, with a smaller percentage arising from acquiring or extracting raw materials. A typical pair of running shoes comprises 65 discrete parts requiring more than 360 processing steps to assemble, from sewing and cutting to injection molding, foaming and heating. These processes are energy-intensive - and therefore, carbon-intensive - compared with the energy that goes into making shoe materials, such as polyester and polyurethane.

In 2010, nearly 25 billion shoes were purchased around the world, the majority of them manufactured in China and other developing countries. The bulk of emissions come from manufacturing. While part of the manufacturing footprint is attributable to a facility's energy source, other emissions came from processes such as foaming and injection molding of parts of a sneaker's sole, which expend large amounts of energy in the manufacture of small, lightweight parts.

In tallying the carbon emissions from every part of a running shoe's life cycle, the researchers were also able to spot places where reductions might be made. For example, they observed that manufacturing facilities tend to throw out unused material. "We are often restricted to quantifying the environmental impacts of material production only, since the manufacturing data is either not readily available or proprietary," says Khanna, assistant professor of civil and environmental engineering at the University of Pittsburgh who did not participate in the research. He adds that knowing the manufacturing contribution may help companies find more effective ways to reduce a product's carbon footprint 


\subsection{Objectives}

This entails the general objectives and specific objectives.

\subsubsection{General Objectives}

To determine the effects of adopting green procurement on the supply chain performance at Bata shoe company in Kenya

\subsubsection{Specific Objectives}

i. To find out environmental factors affecting supply chain performance at Bata shoe company in Kenya

ii. To determine how green procurement tools affect the supply chain performance at Bata shoe company in Kenya

iii. To explore the potential challenges faced by green procurement on the supply chain performance at Bata shoe company in Kenya

\subsection{LITERATURE REVIEW}

\subsection{Theoretical review}

Theoretical review refers to putting forward opinions of theories to give good understanding of previous research works and help to identify and analyze important factors and relationships within envisaged situations (Simons, 2009). Different theories have been employed.

\subsubsection{Strategic Choice Theory}

Strategic Choice Theory describes the role that leaders or leading groups play in influencing an organization through making choices in a dynamic political process. Previous to this theory, a common view was that organizations were thought to be designed along operational requirements based on the external environment. Strategic choice theory provided an alternative that emphasized the agency of individuals and groups within organizations to make choices, sometimes serving their own ends, that dynamically influenced the development of those organizations. These strategic choices formed part of an organizational learning process that adapted to the external environment as well as the internal political situation.

Apart from (but complimentary to) organizational settings, Strategic Choice theory was studied with regard to individual's responses in ordinary, everyday disputes. Findings include that both complainants and respondents used a variety of strategies that changed over time in an effort to resolve the dispute.

\subsubsection{The Economic Theory of Pollution Control}

From a purely economic perspective, the management of environmental quality or pollution control is easily understood if the problem is viewed as minimizing total waste disposal costs.

In minimizing this cost, the underlying economic logic is this. A dollar's worth of investment (expenditure) on pollution control technology will make sense if, and only if, society is expected to be compensated by the benefits to be realized from the avoidance of environmental damage that worth's more than a dollar

Pollution control costs represent direct monetary expenditures by society for the purpose of procuring resources to improve environmental quality or to control pollution. Examples are: Sewage treatment facilities, smoke stacks, soundproof walls and catalytic converters on 
passengers cars. In general, we would expect the marginal pollution control cost to increase with increased environmental quality or cleanup activities. This is because incrementally higher levels of environmental quality require investments in technologies that are increasingly costly.

\subsubsection{Resource Based View Theory}

The source of an organization competitive advantage lies mainly in how it exploits its distinctive internal resources and competence by setting strategic objectives based on what they enable it to (David, 2011). The resource based approach starts with the organizations strengths and seeks an environment that will enable it exploit them by changing environments to suit what it does best rather than changing what it does best to fit the environment (Kincoro, 2005). One of the key insights of the resource based view is that not all organizational resources are a potential source of competitive advantage (hilt, 2011). However, in order to be competitive, resources must be valuable by being capable of creating customers value allowing the firms to implement strategies that will enable it to meet customers' needs more efficiently and effectively, rare and in high demand, difficult for competitors to imitate and difficult for competitors to substitute (Sampurno, 2010)

\subsection{Empirical Literature}

The case of Hanjiang Dafu and Putian Hanjiang shoe companies highlights how Chinese suppliers are improving environmental performance as a result of the green supply chain policies of their international buyers and growing domestic pressure from the Chinese government policies and civil society organizations. Some of these Chinese manufacturers have been able to reduce their environmental impacts by adopting practical and low-cost measures and receiving technical assistance from their multinational buyers and NGOs. However, Chinese suppliers continue to face significant barriers to improving environmental performance - most challenging are the high costs of such green investments and the lack of financial incentives from their buyers. As a result, only a minority of Chinese firms are becoming green supply chain suppliers.

Using the public disclosure of the companies' environmental records, Chinese nongovernmental organizations (NGOs) notified the shoe manufacturers' key customer-Walmart - of these continued pollution violations. In response, Walmart demanded that their suppliers solve their pollution problem if they wanted to continue to do business with the multinational. Within a year and under the supervision of the Chinese NGOs the companies cleaned up their air and wastewater emissions by utilizing the municipal environmental cleanup facilities. To this day, Hanjiang Dafu and Putian Hanjiang maintain their relationship with Walmart.

\subsection{RESEARCH METHODOLOGY}

This study adopted descriptive research design The target population was 120 employees working in different levels of management who are directly involved in managing distribution activities in the organization. The sampling frame was the Human Resource register at BATA Kenya. The population sample was 120 respondents. Structured questionnaires containing both open ended and closed ended questions were used to collect primary data. The questionnaires were filled and returned for analysis. The data collected was analyzed using descriptive statistics like percentages, standard deviations, frequency tables among others. The Statistical Package for Social Sciences (SPSS) Version 17 software was used. 


\subsection{RESEARCH FINDINGS AND DISCUSSION}

\subsection{General Information}

The respondents were asked to indicate their age bracket. Respondents aged 30-39 years were $40.5 \%$ while respondents aged $40-49$ years and above 50 years were $21.6 \%$ each. Only $16.2 \%$ of the respondents were aged 20-29 years. The results show that managers at BATA are middle aged and therefore more likely to be experienced in their respective fields. Table 1 shows the results.

Table 1: Respondents distribution by Age bracket

\begin{tabular}{lccc}
\hline & Frequency & Percent & Cumulative Percent \\
\hline 20-29 years & 6 & 16.2 & 16.2 \\
30-39 years & 15 & 40.5 & 56.8 \\
40-49 years & 8 & 21.6 & 78.4 \\
50 years and above & 8 & 21.6 & 100.0 \\
Total & $\mathbf{3 7}$ & $\mathbf{1 0 0 . 0}$ & \\
\hline
\end{tabular}

The researcher wanted to know respondents' highest level of education. Majority of the respondents were found to be graduates (62.2\%) while $21.6 \%$ of the respondents had post graduate qualifications. Only $16.2 \%$ of the respondents had tertiary or college as their highest level of education. Figure 1 shows the results.

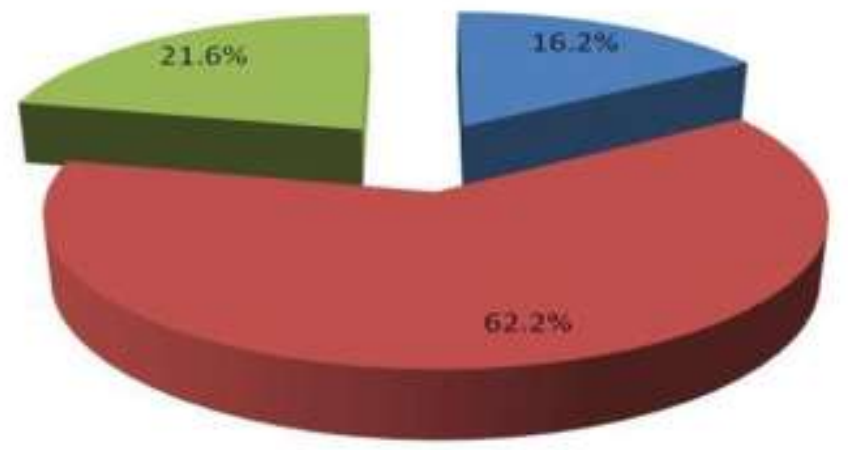

$=$ Tertiary/college

= Graduate

= Postgraduate

\section{Figure 1: Highest level of education}

The respondents were asked to indicate the duration that they had worked at BATA. Respondents who had worked at BATA for 5-10 years were 40.5\% while those that had worked for 10-15 years were $27 \%$. Respondents who had worked at BATA for 15-20 years were $21.6 \%$ while only $10.8 \%$ of the respondents indicated that they had worked at BATA between $0-5$ years. Table 2 shows the results.

\section{Table 2: Duration worked at BATA}




\begin{tabular}{lccc}
\hline Frequency & Percent & Percent & Cumulative Percent \\
\hline 0-5 years & 4 & 10.8 & 10.8 \\
5-10 years & 15 & 40.5 & 51.4 \\
10-15 years & 10 & 27 & 78.4 \\
15-20 years & 8 & 21.6 & 100 \\
Total & $\mathbf{3 7}$ & $\mathbf{1 0 0}$ & \\
\hline
\end{tabular}

The respondents were asked to indicate their position at BATA. Respondents who indicated their position as lower level manager were $45.9 \%$ while middle level managers and senior managers were $32.4 \%$ and $21.6 \%$ respectively. Table 3 shows these results.

\section{Table 3: Position at BATA}

\begin{tabular}{lcrc}
\hline & Frequency & Percent & Cumulative Percent \\
\hline Senior manager & 8 & 21.6 & 21.6 \\
Middle level manager & 12 & 32.4 & 54.1 \\
Lower level manager & 17 & 45.9 & 100.0 \\
Total & $\mathbf{3 7}$ & $\mathbf{1 0 0 . 0}$ & \\
\hline
\end{tabular}

\subsection{Organizational policy}

The respondents were asked to indicate the extent that adoption of sustainable procurement policy on supply chain performance at BATA. Majority of the respondents indicated to a great extent $(59.5 \%$ ) while $32.4 \%$ of the respondents indicated to a moderate extent. Only $8.1 \%$ of the respondents indicated that adoption of sustainable procurement policy on supply chain performance at BATA to a little extent. Table 4 shows these results.

Table 4: Adoption of sustainable procurement policy on organizational performance at BATA

\begin{tabular}{lccc}
\hline Frequency & Frequency & Percent & Cumulative Percent \\
\hline To a little extent & 3 & 8.1 & 8.1 \\
To a moderate extent & 12 & 32.4 & 40.5 \\
To a great extent & 22 & 59.5 & 100 \\
Total & $\mathbf{3 7}$ & $\mathbf{1 0 0}$ & \\
\hline
\end{tabular}

Respondents were asked to indicate the extent they agree or disagree with three statements in regard to influence on the policy on supply chain performance at BATA. They were to use a five point Likert scale where $1=$ strongly disagree, $2=$ disagree, $3=$ neutral, $4=$ agree, and $5=$ strongly agree. The results show that respondents agreed with the statement that sustainable procurement policy positively affected supply chain performance at BATA $(\mathrm{M}=4.09, \mathrm{SD}=.348)$. The respondents also agreed with the statement that there is a reduction in legal environmental issues due to adoption of procurement policies $(\mathrm{M}=4.00, \mathrm{SD}=.458)$. The respondents were neutral on the statement that there are better human resource management practices at BATA that can be attributed to adoption of procurement policies $(\mathrm{M}=3.89, \mathrm{SD}=.718)$ 
Table 5: Sustainable procurement policy

\begin{tabular}{lccc}
\hline & N & Mean & Std.DEv \\
\hline $\begin{array}{l}\text { Synchronization of functions has been enhanced by organizational } \\
\text { policy on JIT at BATA }\end{array}$ & 37 & 4.09 & 0.348 \\
$\begin{array}{l}\text { There is a reduction in legal cases do to adoption of sustainable } \\
\text { procurement policies }\end{array}$ & 37 & 4 & 0.458 \\
$\begin{array}{l}\text { There are better human resource management practices at BATA that } \\
\text { can be attributed to organizational adoption of sustainable } \\
\text { procurement policies }\end{array}$ & 37 & 3.89 & 0.718 \\
Valid N (listwise) & 37 & & \\
\hline
\end{tabular}

\subsection{Cost Control}

The respondents were asked to indicate whether adoption of green procurement had an influence on cost at BATA. Majority of the respondents (89.2\%) indicated yes as compared to $10.8 \%$ of the respondents who indicated no. Figure 2 shows these results.

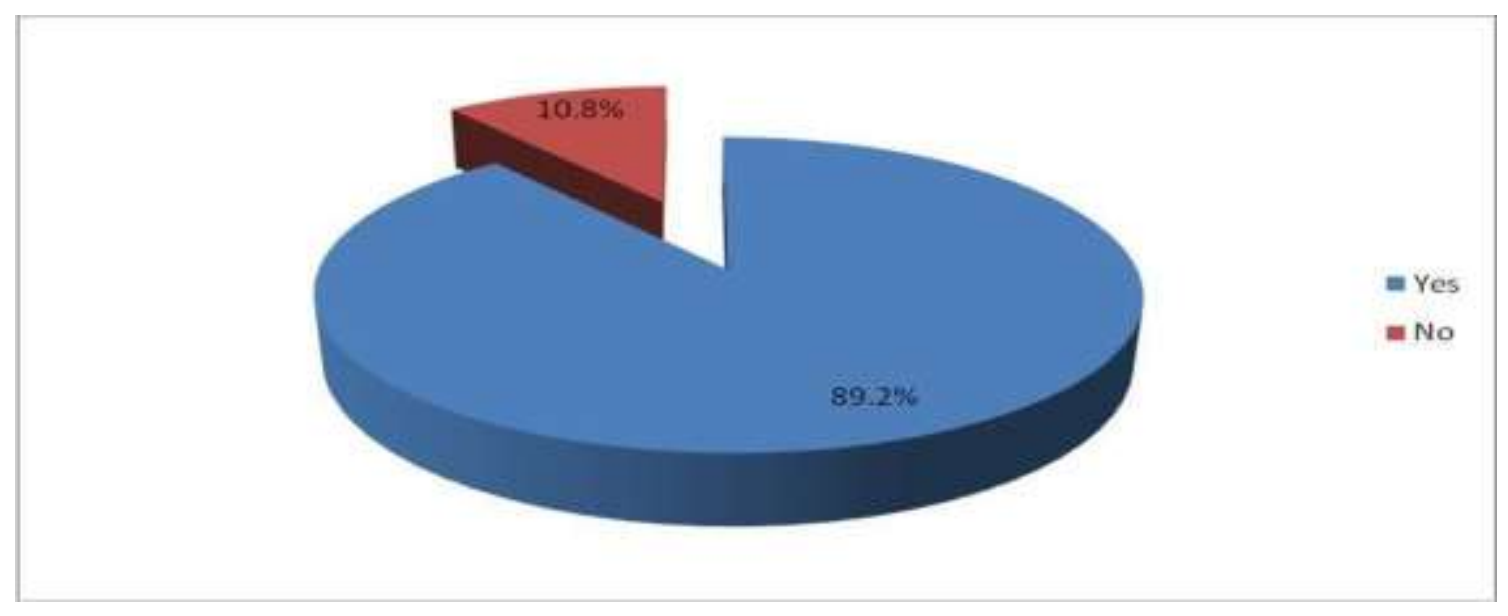

Figure 2: Adoption of green procurement on cost at BAT

Respondents were asked to indicate the extent they agree or disagree with three statements in regard to information technology integration on JIT at BATA. They were to use a five point likert scale where $1=$ strongly disagree, $2=$ disagree, $3=$ neutral, $4=$ agree, and $5=$ strongly agree. The results show that respondents agreed with the statement that adoption of sustainable procurement policies has brought about profitability at BATA $(\mathrm{M}=4.33, \mathrm{SD}=.471)$ and that identification of alternative raw materials has led to cost reduction $(\mathrm{M}=4.11, \mathrm{SD}=.403)$. Respondents also agreed with the statement that recycling policy has brought down cost incurred by the organization $(\mathrm{M}=4.00, \mathrm{SD}=.372)$. Table 6 shows these results.

\section{Table 6: Cost control}




\begin{tabular}{lccc} 
& N & Mean & Std. DEv \\
\hline $\begin{array}{l}\text { Adoption of sustainable procurement policies has brought about } \\
\text { profitability at BATA }\end{array}$ & 37 & 4.00 & 0.372 \\
$\begin{array}{l}\text { Identification of alternative raw materials has led to cost reduction } \\
\text { Recycling policy has brought down cost incurred by the }\end{array}$ & 37 & 4.33 & 0.471 \\
organization & 37 & 4.11 & 0.403 \\
Valid N (listwise) & $\mathbf{3 7}$ & & \\
\hline
\end{tabular}

\subsection{Information Technology}

The respondents were asked to indicate whether IT had an impact on supply chain performance at BATA. The results have shown that majority of the respondents (94.6\%) indicates yes as compared to $5.4 \%$ of the respondents who indicated no. Figure 3 shows these results

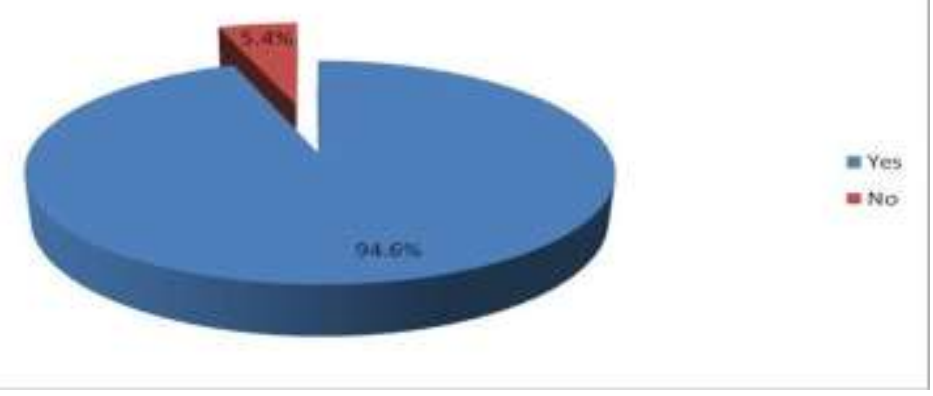

Figure 3: Information Technology affect supply chain performance at BATA

Respondents were asked to indicate their agreement or disagreement with three statements regarding demand management. They were to use a five point likert scale where $1=$ strongly disagree, $2=$ disagree, $3=$ neutral, $4=$ agree, and $5=$ strongly agree. The results showed that respondents agreed with the statements that IT had an impact on reducing paperwork by providing electronic documents at BATA $(\mathrm{M}=4.46, \mathrm{SD}=.730)$ and there is improved accessibility, convenience and productivity by employing effective methods of service delivery at BATA $(\mathrm{M}=4.00, \mathrm{SD}=.707)$. Respondents also agreed with the statement that IT has enabled provision of security of material and information flow throughout the supply chain network at BATA $(\mathrm{M}=4.07, \mathrm{SD}=.687)$. These results are presented in table 7

\section{Table 7: Information Technology}

\begin{tabular}{lcrc}
\hline & N & Mean & Std.DEv \\
\hline Reduce paperwork by providing electronic documents & 37 & 4.07 & 0.687
\end{tabular}

Improving accessibility, convenience and

productivity by employing effective

methods of service delivery

$\begin{array}{lll}37 & 4.00 \quad 0.707\end{array}$

Provision of security of material and information flow throughout the supply chain network

$37 \quad 4.46 \quad 0.730$




\subsection{Quality Management}

Respondents were asked to indicate whether quality management on sustainable procurement affected supply chain performance at BATA. The results show that majority of the respondents $(94.6 \%)$ indicated yes as compared to $5.4 \%$ of the respondents who indicated no. Figure 4 shows these results.

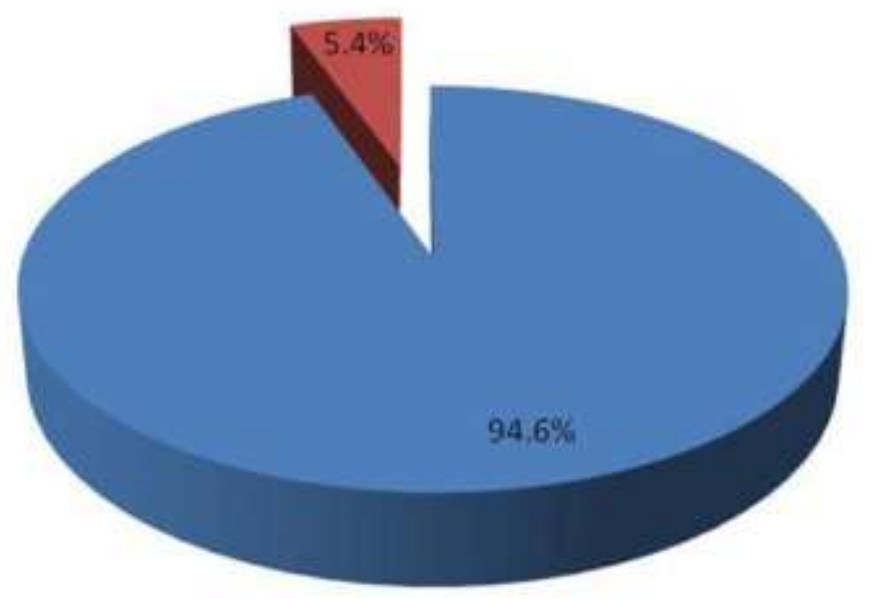

\section{Figure 4: Quality management affect supply chain at BATA}

The respondents were asked to indicate their agreement or disagreement with three statements regarding quality management at BATA. The results show that respondents agreed with the statements that there is continuous improvement as a result of quality management on supply chain $(\mathrm{M}=4.03, \mathrm{SD}=.499)$ and that customer focus in production has been improved as a result of quality management at BATA $(\mathrm{M}=4.03, \mathrm{SD}=.287)$. Respondents were neutral on the statement that quality management has strengthened quality control at BATA $(\mathrm{M}=3.86, \mathrm{SD}=.481)$ The table 8 shows the results

\section{Table 8: Quality Management}

\begin{tabular}{llrrr}
\hline & N & Mean & Std. DEv \\
\hline $\begin{array}{l}\text { Quality management has strengthened quality control at BATA } \\
\text { There is continuous improvement as a result of quality }\end{array}$ & 37.86 & 0.481 \\
management & 37 & 4.03 & 0.489 \\
$\begin{array}{l}\text { Customer focus in production has been improved as a result of } \\
\text { quality management at BATA }\end{array}$ & 37 & 4.03 & 0.287 \\
Valid N (listwise) & $\mathbf{3 7}$ & & \\
\hline
\end{tabular}




\subsection{Organizational Performance}

Respondents were asked to indicate whether sustainable procurement affected organizational performance at BATA. The results showed that majority of the respondents $(94.6 \%)$ indicated yes as compared to $5.4 \%$ of the respondents who indicated no. Figure 5 shows the results
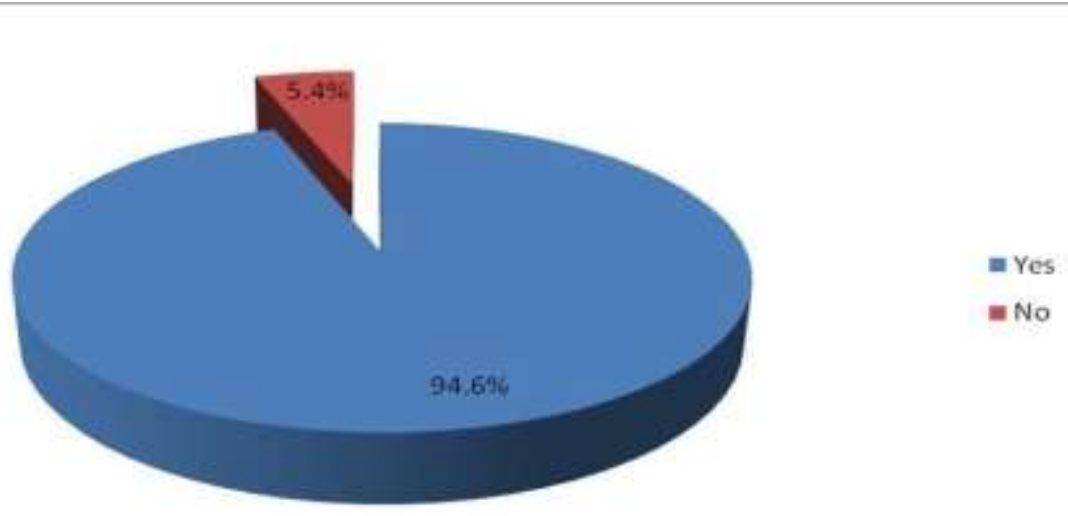

Figure 5: sustainable procurement affect organizational performance at BATA

The respondents were asked to indicate their agreement or disagreement with three statements that measure supply chain performance. The results indicated that respondents agreed with the statements that profitability has increased as a result of sustainable procurement at BATA $(\mathrm{M}=4.68, \mathrm{SD}=.580)$ and efficiency and effectiveness has improved as a result of sustainable procurement at BATA(M=4.24, $\mathrm{SD}=.723)$. Respondents were neutral on the statement that BATA has a bigger market share that can be attributed to sustainable procurement in the firm $(\mathrm{M}=3.78, \mathrm{SD}=.584)$. Table 9 shows these results.

\section{Table 9: Supply Chain Performance}

\begin{tabular}{lcrc}
\hline & N & Mean & Std.DEv \\
\hline $\begin{array}{l}\text { Profitability has increased as a result of sustainable procurement } \\
\text { BATA has a bigger market share that can be attributed to }\end{array}$ & 37 & 4.68 & 0.580 \\
sustainable procurement & 37 & 3.78 & 0.384 \\
Efficiency and effectiveness has improved as a result of & & & \\
Sustainable procurement & 37 & 4.24 & 0.723 \\
Valid N (listwise) & $\mathbf{3 7}$ & & \\
\hline
\end{tabular}




\subsection{Regression Analysis Results}

A multiple linear regression analysis was done to examine the relationship of the independent variables with the dependent variable. The model summary table shows that $81 \%$ of change in organizational performance can be explained by four predictors namely sustainable procurement policy, cost control, information technology, and product quality.

Table 10: Model Summary

\begin{tabular}{lrrrr}
\hline Model & R & R Square & Adjusted R Square & \multicolumn{2}{c}{$\begin{array}{c}\text { Std. Error of the } \\
\text { Estimate }\end{array}$} \\
\hline 1 & $.912^{\mathrm{a}}$ & .831 & .810 & .14175 \\
\hline
\end{tabular}

Predictors: (Constant), sustainable procurement policy, cost control, information technology, and product quality.

Analysis of variance (ANOVA) was done to establish the fitness of the regression model used. The ANOVA table shows that the F-ratio $(\mathrm{F}=39.434, p=.000)$ was statistically significant. This means that the model used was appropriate and the relationship of the variables shown could not have occurred by chance.

Table 11: ANOVA

\begin{tabular}{lrrrrr}
\hline Model square & sum of df & \multicolumn{1}{c}{ square } & \multicolumn{1}{c}{ Mean } & \multicolumn{2}{c}{ F } \\
\hline Regression & 3.169 & 4 & 0.792 & 39.434 & $.000 \mathrm{~b}$ \\
Residual & 0.643 & 32 & 0.02 & & \\
Total & $\mathbf{3 . 8 1 2}$ & $\mathbf{3 6}$ & & & \\
\hline
\end{tabular}

Predictors: (Constant), sustainable procurement policy, cost control, information technology, and product quality.

The coefficients of determination show the contribution of each independent variable to the change in the dependent variable. The coefficients table results show that Sustainable procurement policy $(\beta=.144, p=.026)$ positively and significantly affected supply chain performance at BATA. The results also show that cost control $(\beta=.198, p=.008)$ positively and significantly affected organizational performance at BATA. Information Technology $(\beta=.229$, $p=.001)$ and Product Quality $(\beta=.607, p=.000)$ were found to positively and significantly affect supply chain performance at BATA.

Table 12: Coefficients of Determination

\begin{tabular}{|c|c|c|c|c|}
\hline & B & Std. Error & $\mathbf{t}$ & Sig. \\
\hline (Constant) & -.631 & 0.407 & 1.549 & 0.131 \\
\hline Sustainable Buying Policy & 0.144 & 0.062 & 2.336 & 0.026 \\
\hline Cost Control & 0.198 & 0.070 & 2.851 & 0.008 \\
\hline
\end{tabular}




\begin{tabular}{lllll} 
Information Technology & 0.229 & 0.066 & 3.486 & $\mathbf{0 . 0 0 1}$ \\
Product Quality & 0.607 & 0.124 & 4.901 & $\mathbf{0 . 0 0 0}$ \\
\hline
\end{tabular}

\subsection{SUMMARY, CONCLUSION AND RECOMMENDATIONS}

\subsection{Summary of Findings}

The results revealed that organizational sustainable procurement policy affected supply chain performance at BATA to a great extent (59.5\%). The results have also shown that Organizational Policy $(\beta=.144, p=.026)$ positively and significantly affected supply chain performance at BATA.

The findings have also shown that cost control affected organizations performance to a great extent $(89.2 \%)$. Cost control $(\beta=.198, p=.008)$ also positively and significantly affected supply chain performance at BATA.

The findings have shown that IT affected organizational performance at BATA to a great extent (94.6\%). The results further show that Information Technology $(\beta=.229, p=.001)$ was also found to positively and significantly affect supply chain performance at BATA.

The results have revealed that product quality (94.6\%) affect supply chain performance at BATA. Product Quality $(\beta=.607, p=.000)$ was also found to positively and significantly affect supply chain performance at BATA.

\subsection{Conclusion}

This study concluded that having a clear organizational sustainable procurement policy on supply chain performance is important in an organization as it has been found to positively affect supply chain performance. This study also concluded that cost control is also crucial. Evidence have shown that Information Technology Integration in JIT implementation positively affect supply chain performance in organizations. This study concluded that in JIT implementation, it is important to consider the demand management ability as it had been revealed to positively affect supply chain performance. The same applies to quality management in JIT implementation.

\subsection{Recommendations}

This study recommends that BATA should review its organizational policy on JIT implementation to improve its supply chain performance especially in regards to better human resource management practices. BATA should also enhance its Information Technology Integration to promote information sharing and support its ERP systems. This study recommends that BATA should maintain or if possible improve its demand management in regards to forecasting, flexibility and having a contingency management system. The study recommends that BATA should utilize JIT to strengthen its quality control.

\section{REFERENCES}

Anderson,J.C\&John,G. (2006). Alliances in industrial purchasing: The determinants of joint action in buyer-supplier relationships. Journal of Marketing,54(1), 42-58.

David,K. (2011). Resources as competitive advantage: Strategic Inventory Management, 12th edition. Jakarta: Salemba Empta Inc. 
Goldratt,P. (2006). The goal: A process of ongoing improvement. New York : North River Press.

Kuncoro,M. (2005). Competitive advantage in information technology: Strategic Management. Jakarta: Salaemba Empta Inc. 